\title{
Effect of a ready-to-use supplementary food on the recovery of preschool children with malnutrition
}

\author{
Juan O. Talavera, ${ }^{1 *}$ Mónica J. García-Vilchis, ${ }^{2}$ Thanya S. Labrada-Alba, ${ }^{3}$ Fabián Olvera-Flores, ${ }^{3}$ \\ Ma. Fernanda Martínez-Jaureguiberry² and Brenda Salgado-Enríquez² \\ ${ }^{1}$ Directorate of Teaching and Research, Centro Médico ABC; ${ }^{2}$ Life Sciences, Nutrition Sciences, PepsiCo Inc. Global R\&D; ${ }^{3}$ Un Kilo de Ayuda A.C., \\ Division of Operations, Follow-up and Evaluation. Mexico City, Mexico
}

\begin{abstract}
Introduction: In developing countries, protein-energy malnutrition causes $60 \%$ of deaths in children < 5 years of age. Objective: To evaluate the effect of a ready-to-use supplementary food (RUSF) on moderate acute malnutrition (MAM) in preschool children. Method: Clinical trial that included 155 children with MAM (weight/height Z-score > -3 and $\leq-2$ ). Each child received RUSF in the form of biscuits, four per day (250 kcal), for 12 months. The tutor received education on nutrition, health and hygiene. Recovery (weight/height Z-score > -2) at four, six, and 12 months was assessed using intent-to-treat (ITT) and per protocol (PP) analyses. Changes in chronic malnutrition were also analyzed. Results: In the first semester, adequate RUSF consumption was observed in $61 \%$ of the children, and in $42 \%$ in the second semester. In the ITT analysis, $78 \%$ were identified to have recovered, with 38\% reaching normal nutritional values; in the PP analysis, > 90\% recovered and > 40\% reached normal values. Recovery from chronic malnutrition was also observed. Conclusions: The consumption of RUSF and an educational program reduced MAM.
\end{abstract}

KEY WORDS: Ready-to-use supplementary food. Supplementation. Moderate acute malnutrition.

\section{Efecto de un suplemento alimenticio listo para consumir en la recuperación de la desnutrición de niños preescolares}

\section{Resumen}

Introducción: En países en desarrollo, la desnutrición proteico-energética causa 60 \% de las muertes en los niños menores de cinco años. Objetivo: Evaluar el efecto de un suplemento alimenticio listo para consumir (SALC) en la desnutrición aguda moderada (DAM) en niños preescolares. Método: Ensayo clínico que incluyó 155 niños con DAM (puntuación Z de peso/ talla [pZ] mayor de -3 y menor o igual a -2). Cada niño recibió SALC en forma de galletas, cuatro por día (250 kcal), durante 12 meses. El tutor recibió educación sobre nutrición, salud e higiene. La recuperación ( $p Z$ peso/talla mayor de -2) a los cuatro, seis y 12 meses se evaluó con un análisis por intención a tratar (AIT) y por protocolo (APP). También se analizaron cambios en la desnutrición crónica. Resultados: En el primer semestre se observó consumo adecuado del SALC en $61 \%$ de los niños y en $42 \%$ en el segundo semestre. Con el AlT se identificó que $78 \%$ se recuperó y $38 \%$ alcanzó valores normales de nutrición; con el APP, > 90 \% se recuperó y > 40 \% alcanzó valores normales. Se observó recuperación de la desnutrición crónica. Conclusiones: El consumo de SALC y un programa educativo redujeron la DAM.

PALABRAS CLAVE: Suplemento alimenticio listo para consumir. Suplementación. Desnutrición aguda moderada.

\footnotetext{
Correspondence:

Date of reception: 30-12-2020

*Juan O. Talavera

E-mail: jotalaverap@abchospital.com

0016-3813/@ 2021 Academia Nacional de Medicina de México, A.C.. Published by Permanyer. This is an open access article under the CC BY-NC-ND license (http://creativecommons.org/licenses/by-nc-nd/4.0/).
} 


\section{Introduction}

Protein-energy malnutrition is caused by inadequate protein and energy intake. The United Nations Food and Agriculture Organization revealed that, in 2017, there were 821 million people with undernutrition in the world..$^{1-3}$ In children younger than 5 years, it entails a higher risk of morbidity and up to $60 \%$ of mortality. ${ }^{3,4}$ In developing countries, $20 \%$ of children in this age group are underweight (less than -2 standard deviations [SD] of weight-for-age) $32 \%$ are stunted (less than -2 SD of height-for-age), and $10 \%$ are affected by wasting (less than -2 SD of weight-for-height). ${ }^{5}$

In Mexico, in 2012, the prevalence of wasting, underweight and stunting in children aged $\leq 5$ years was $1.6,2.8$, and $13.6 \%$, respectively. In rural areas, undernutrition was $24.1 \%$, and in indigenous groups, $34.1 \%$. 6,7 The two main causes are food insecurity and insufficient consumption of nutritious foods; $18.2 \%$ of Mexicans have no access to adequate food. ${ }^{8}$ The highest prevalence of food insecurity is recorded in Chiapas (47\%), Guerrero (42\%) and Oaxaca $(38 \%){ }^{6}$

A ready-to-use supplementary food (RUSF) was designed to supplement usual diet and support recovery from moderate malnutrition in preschool children from rural communities in Mexico. ${ }^{9}$

Most studies that address acute undernutrition have found that stopping supplementation after recovery can lead to undernutrition relapses and worsening. ${ }^{10-12}$ In Panama, nine months after having started a program with a nutritional supplement, $35 \%$ of children with undernutrition and $24 \%$ of children at risk thereof were observed to improve or normalize their nutritional status. ${ }^{13}$

Our objective was to evaluate the effect of an educational program with consumption of a RUSF in the form of a biscuit for 12 months on the recovery of moderate acute malnutrition (MAM) in preschool children from rural areas of Mexico.

\section{Methods}

An experimental, single-group, before-after clinical trial was carried out in regions of the states of Oaxaca, Chiapas and the State of Mexico, given the high prevalence of MAM in children aged $\leq 5$ years.

Participants were children of between two and five years of age with MAM, defined as a weight-for-height

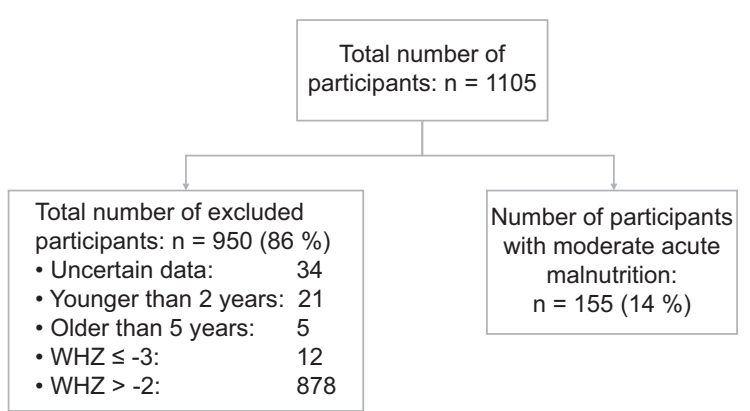

Figure 1. Flowchart of the selection process of children with moderate acute malnutrition (weight-for-height Z-score from $>-3$ to $\leq-2$ ).

Z-score (WHZ) between $>-3$ and $\leq-2$, according to the World Health Organization growth standards (Fig. 1); the children belonged to the lowest socioeconomic strata and had a legal guardian who authorized their participation in the study. Children with clinical signs of micronutrient deficiency, acute diarrheal or respiratory infection, consumption of other supplements or a history of peanut allergy were excluded. Children with severe acute malnutrition $(\mathrm{WHZ} \leq-3$ $\mathrm{SD}$ ) or disease were referred to a health clinic for treatment.

During the intervention, each child received one RUSF daily serving, four biscuits per day (250 kcal) for 12 months. The product contains high-quality protein, is energy-dense, and is fortified with vitamins and minerals, in accordance with the World Health Organization criteria for the treatment of undernutrition ${ }^{9}$ (Supplementary Table 1). The RUSF was produced at PepsiCo facilities in Guanajuato, Mexico, requires no preparation and has a long shelf-life.

Legal guardians underwent a nutrition, health and hygiene education program (Supplementary Table 2), where a facilitator used printed/graphic materials to improve understanding. Each topic was presented in 20-minute practical sessions every 14 days. Offering RUSF to the child twice a day as a snack to achieve the consumption of a full portion was indicated, as well as not to replace any food of their usual diet, maintaining the three main meals. Each family was instructed not to share the study RUSF within the family, for which differently-packaged additional RUSFs were provided.

A participant was considered to comply with RUSF adequate consumption if it was $\geq 60 \%$ during each semester ( $150 \mathrm{kcal} /$ day). Consumption monitoring was carried out with monthly interviews with the legal guardians, and collection of empty packages and 
unused product. RUSF consumption percentages were calculated based on the number of biscuits consumed per month divided by the number of biscuits that should have been consumed.

The facilitators carried out monthly monitoring of adverse events in order to assess safety, which were classified according to the adverse drug reactions probability scale. ${ }^{14}$ In case of acute gastrointestinal disease, respiratory distress, altered consciousness, fever or hospitalization for any reason, interruption of the use of RUSF was indicated until the resolution of these alterations or until the doctor considered it pertinent. Children who developed severe undernutrition during follow-up (Z-score $\leq-3$ ) were regarded as therapeutic failure, were referred for medical care and were followed-up until completing one year.

Data on socioeconomic and demographic aspects, consumption of food and supplements were collected using standardized questionnaires. Anthropometric measurements were carried out using standard methods. ${ }^{15,16}$ A digital scale was used, with $200 \mathrm{~g}$ for clothing being subtracted. Height was measured using a SECA $213^{\circledR}$ stadiometer. Weight-for-age (WAZ), height-for-age (HAZ), and weight-for-height (WHZ) Z-scores were calculated with the World Health Organization reference standards..$^{17}$ Hemocue $\mathrm{Hb} 201^{\circledR}$ (Hemocue, Mexico) was used to measure hemoglobin; iron-deficiency anemia was treated with Ferranina ${ }^{\circledR}$ iron polymaltose as part of a protocol of the non-governmental organization that participates in the program.

The purpose and dynamics of the study were explained to legal guardians. Visits at four, six, and 12 months included a physical and anthropometric examination and monitoring of compliance, child behavior, and adverse events.

\section{Ethics}

The protocol was approved by the Autonomous University of the State of Mexico ethics committee. The legal guardians signed an informed consent document after receiving an explanation on the purpose and procedures of the study. The participants were free to withdraw from the study at any time.

\section{Statistical analysis}

A WHZ > -2 was considered a successful outcome. Statistical power analysis indicated that, given an expected success rate of $65 \%$, the sample size required for estimating a confidence interval within one tenth of the expected success rate $(6.5 \%)$ was 207 subjects. ${ }^{18}$

MAM resolution rate and its associated $95 \%$ confidence intervals were estimated using an intent-to-treat (ITT) analysis and per-protocol (PP) analysis. Changes in participants' Z-scores were assessed by comparing baseline status with the results of the intervention at different time points. Mean differences were determined by analysis of variance. A p-value $\leq$ 0.05 was regarded as a statistically significant result.

\section{Results}

Baseline characteristics of participants are shown in table 1. One hundred and fifty-five children were eligible. Mean age $( \pm S D)$ was $38 \pm 9$ months, WHZ was $-0.31 \pm 0.25$, WAZ was $-2.64 \pm 0.77$ and $\mathrm{HAZ}$ was $-1.89 \pm 1.31$.

The degree of adherence to RUSF consumption was $61 \%(n=94)$ during the first semester and $42 \%$ ( $n=65$ ) during the second (Table 2).

Success (recovery from MAM) in the ITT analysis was $78 \%$, and normal values were reached in $38 \%$ of children $(\mathrm{WHZ}<-1)$. In the PP analysis with adherence during the first semester, success was $>90 \%$ and $44 \%$ reached normality; in those who were adherent during the second semester, success was $91 \%$ and normalization was observed in $46 \%$ (Table 3).

Mean WAZ gain was 1.67; baseline value was -2.58 \pm 0.07 , at four months it was $-1.62 \pm 0.08$, at six months it was $-1.44 \pm 0.08$ and at 12 months it was $-0.91 \pm 0.09$ ( $p=0.0001$ vs. baseline value). Similarly, a mean HAZ improvement of 1.65 was observed and normal values were reached at six months: on baseline measurement it was $-1.79 \pm 0.12$, at four months it was $-1.19 \pm 0.12$, at six months it was $-0.80 \pm 0.12$, and at 12 months it was $-0.14 \pm 0.13$ ( $p=0.0001$ vs. baseline value). There was a progressive improvement in WHZ from baseline to months 4 and 6 , and normal values were reached at 12 months (Table 4 and Fig. 2).

During the first month, there was an incidence of respiratory tract infections of $42 \%$, which decreased to $15 \%$ at month 4 ; infectious gastroenteritis incidence was $20 \%$ at baseline and progressively decreased to $3 \%$ at month 5 and to $0 \%$ at month 6 (Table 5). 
Table 1. Baseline and demographic characteristics of 155 participants with MAM

\begin{tabular}{|c|c|}
\hline Characteristics & Mean \pm SD \\
\hline Age, months & $38 \pm 9$ \\
\hline Height, cm & $89 \pm 8$ \\
\hline Weight, kg & $10 \pm 2$ \\
\hline HAZ & $-1.89 \pm 1.31$ \\
\hline WAZ & $-2.64 \pm 0.77$ \\
\hline WHZ & $-2.31 \pm 0.25$ \\
\hline Protein consumption, times/week & $\begin{array}{l}\text { Median }\left(25^{\text {th }} \text { and } 75^{\text {th }}\right. \\
\text { percentiles })\end{array}$ \\
\hline Meat & 4 (3 and 7) \\
\hline Milk & 7 (1 and 7$)$ \\
\hline Eggs & 3 (2 and 5) \\
\hline Total protein per week & Approximately $100 \mathrm{~g}$ \\
\hline Supplements & Percentage \\
\hline Vitamins & 17.4 \\
\hline Iron supplements & 8.4 \\
\hline \multicolumn{2}{|c|}{$\begin{array}{l}\text { Legal guardian demographic characteristics (mother, father, } \\
\text { grandparent) }\end{array}$} \\
\hline $\begin{array}{l}\text { Gender } \\
\text { Males } \\
\text { Females }\end{array}$ & $\begin{array}{l}57 \\
43\end{array}$ \\
\hline $\begin{array}{l}\text { Language } \\
\text { Spanish } \\
\text { Indigenous }\end{array}$ & $\begin{array}{l}84 \\
16\end{array}$ \\
\hline $\begin{array}{l}\text { Marital status } \\
\text { Married } \\
\text { Cohabitating } \\
\text { Single }\end{array}$ & $\begin{array}{l}65 \\
25 \\
10\end{array}$ \\
\hline $\begin{array}{l}\text { Years of formal education } \\
\text { None } \\
1-6 \\
7-9 \\
\text { More than } 10\end{array}$ & $\begin{array}{l}11 \\
37 \\
33 \\
19\end{array}$ \\
\hline $\begin{array}{l}\text { Stays home during the day } \\
\text { Yes }\end{array}$ & 88 \\
\hline $\begin{array}{l}\text { Number of children in the family } \\
1-2 \\
3-4 \\
\geq 5\end{array}$ & $\begin{array}{l}56 \\
30 \\
14\end{array}$ \\
\hline
\end{tabular}

\section{Discussion}

Consistent with the parameters recommended in other studies for considering a successful outcome with the consumption of RUSF ( $\geq 75 \%),{ }^{19-21}$ in the ITT
Table 2. Degree of adherence to the consumption of the ready-to-use supplementary food

\begin{tabular}{|l|c|c|}
\hline \multirow{2}{*}{ Degree of adherence } & \multicolumn{2}{|c|}{ Time } \\
\cline { 2 - 3 } & First semester & Second semester \\
\hline$\geq 60 \%$ & $61 \%$ & $42 \%$ \\
\hline$<60 \%$ & $30 \%$ & $32 \%$ \\
\hline None & $9 \%$ & $26 \%$ \\
\hline
\end{tabular}

$\geq 60 \%$ was considered adequate; $<60 \%$, moderate.

Table 3. Recovery from moderate acute malnutrition (MAM) after 12 months of supplementation with RUSF

\begin{tabular}{|c|c|c|}
\hline \multirow[t]{2}{*}{ Type of analysis } & \multicolumn{2}{|c|}{ MAM resolution } \\
\hline & Recovery* & Normal ${ }^{* *}$ \\
\hline ITT, n (\%) & $121 / 155(78 \%)$ & $59 / 155(38 \%)$ \\
\hline PP & & \\
\hline Adherence first semester, $\mathrm{n}(\%)$ & $87 / 94(92 \%)$ & $41 / 94(44 \%)$ \\
\hline $\begin{array}{l}\text { Adherence second semester, } \\
\mathrm{n}(\%)\end{array}$ & $59 / 65(91 \%)$ & $30 / 65(46 \%)$ \\
\hline
\end{tabular}

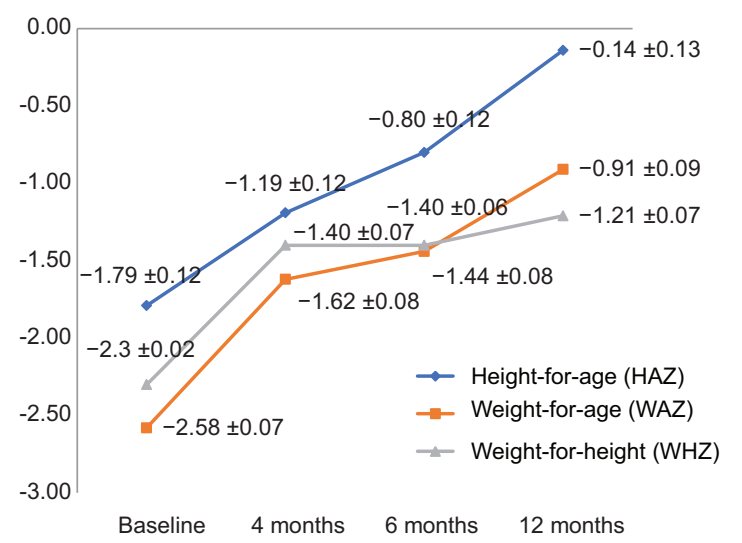

Figure 2. Effect of RUSF-biscuit consumption on anthropometric indicators in children with moderate acute malnutrition (Z-score values). The results of all comparisons with associated baseline values were significant (repeated measures ANOVA, $p<0.0001$ ).

analysis, our study showed $78 \%$ of success in recovery from MAM, whereby a reduction in mortality is expected. ${ }^{16}$ Intervention time, RUSF acceptance and ease of consumption, in addition to the educational strategy, favored successful recovery from MAM.

Some successful interventions with shorter duration show that $50 \%$ of children usually relapse after 
Table 4. Effect of RUSF consumption on anthropometric indicators in children with moderate acute malnutrition

\begin{tabular}{|c|c|c|c|c|c|}
\hline \multirow[t]{2}{*}{ Z-scores (mean \pm SE) } & \multirow{2}{*}{$\begin{array}{c}\text { No supplement } \\
\text { Baseline }\end{array}$} & \multicolumn{3}{|c|}{ With RUSF supplement } & \multirow[t]{2}{*}{${ }^{\& p}$} \\
\hline & & 4 months & 6 months & 12 months & \\
\hline Weight-for-age & $-2.58 \pm 0.07$ & $-1.62 \pm 0.08$ & $-1.44 \pm 0.08$ & $-0.91 \pm 0.09$ & $\begin{array}{c}0.0001^{*} \\
0.0001^{\star *} \\
0.0001^{\star * *}\end{array}$ \\
\hline Height-for-age & $-1.79 \pm 0.12$ & $-1.19 \pm 0.12$ & $-0.80 \pm 0.12$ & $-0.14 \pm 0.13$ & $\begin{array}{c}0.0001^{*} \\
0.0001^{* *} \\
0.0001^{\star * \star}\end{array}$ \\
\hline Weight-for-height & $-2.30 \pm 0.02$ & $-1.40 \pm 0.07$ & $-1.40 \pm 0.06$ & $-1.21 \pm 0.07$ & $\begin{array}{c}0.0001^{*} \\
0.0001^{* *} \\
0.0001^{* * *}\end{array}$ \\
\hline
\end{tabular}

SE: standard error. ${ }^{\circledR}$ Repeated measures ANOVA. *Baseline vs. 4 months. **Baseline vs. 6 months. ${ }^{* * *}$ Baseline vs. 12 months. RUSF: ready-to-use supplementary food.

Table 5. Frequency of associated comorbidities in children who consumed RUSF

\begin{tabular}{|c|c|c|}
\hline Period & Comorbidity & Percentage \\
\hline \multirow[t]{3}{*}{ Month 1} & Probable infectious gastroenteritis & 20 \\
\hline & Upper respiratory tract infection & 42 \\
\hline & Fever & 10 \\
\hline \multirow[t]{3}{*}{ Month 2} & Probable infectious gastroenteritis & 18 \\
\hline & Upper respiratory tract infection & 29 \\
\hline & Fever & 6 \\
\hline \multirow[t]{3}{*}{ Month 3} & Probable infectious gastroenteritis & 10 \\
\hline & Upper respiratory tract infection & 27 \\
\hline & Fever & 2 \\
\hline \multirow[t]{3}{*}{ Month 4} & Probable infectious gastroenteritis & 7 \\
\hline & Upper respiratory tract infection & 15 \\
\hline & Fever & 2 \\
\hline \multirow[t]{3}{*}{ Month 5} & Probable infectious gastroenteritis & 3 \\
\hline & Upper respiratory tract infection & 14 \\
\hline & Fever & 0 \\
\hline \multirow[t]{3}{*}{ Month 6} & Probable infectious gastroenteritis & 0 \\
\hline & Upper respiratory tract infection & 14 \\
\hline & Fever & 0 \\
\hline
\end{tabular}

The children were visited every 15 days, but only one associated disease was considered per month in the following order: lower respiratory tract infection, probable infectious gastroenteritis, upper respiratory tract infection, fever. RUSF=ready-to-use supplementary food.

recovery from MAM, and that severe acute undernutrition can occur in up to $10 \%$, and that $4 \%$ can die from this cause..$^{10-12}$

This study analyzed a longer treatment time in comparison with similar protocols,,$^{10-12,19}$ during which an initial rapid recovery was achieved at month 4 and, subsequently, slower but constant for 12 months; 38\% of the children reached normal weight, and supplementation for 12 months is therefore expected to result in lower relapse rates.

During the first 6 months of the study there was a high degree of adherence ( $61 \%$ adequate), followed by adherence rates of $42 \%$ (adequate) during the second semester, in comparison with $57 \%$ of food puree regular consumption reported at 12 months in the PROGRESA program..$^{22,23}$

Other studies have shown that the costs associated with RUSF limit its use; ${ }^{24}$ however, better recovery rates are observed in comparison with conventional programs where the food is prepared at home,$^{18}$ with the benefit that, with RUSFs, no additional preparation is required, whereby the risk of contamination is reduced. ${ }^{25}$ Our RUSF had good acceptance, which reflected on adherence; it does not produce organoleptic changes associated with its consumption, unlike food puree added with different types of iron. ${ }^{23}$ In addition, the proposed RUSF has a shelf life of six months, in contrast to the product developed in Peru, which only has a 60-day shelf life. ${ }^{26}$

A cohort study in Peru showed that an educational program by itself leads to growth improvements. ${ }^{27}$ However, if a sum of strategies is carried out, higher efficacy is observed in interventions, as documented by Dewey et al. in their systematic review. ${ }^{28}$

Study strengths included long-term treatment, low probability of contamination, and high acceptance by children and legal guardians, which resulted in a comprehensive intervention. The improvement observed in nutritional status, secondary to the consumption of RUSF in conjunction with health, hygiene and nutrition education, could favor the recovery from MAM. On the 
other hand, we tried to act responsibly by supplying RUSF to the entire group, given the risk of undernutrition progression in children under this conditions without nutritional support. The nutritional improvement observed in this group of patients further confirms the benefit previously observed in a clinical trial conducted with the same RUSF in children with MAM. ${ }^{29}$

The limitations of the study include underreporting of incidents by legal guardians, which resulted in an overestimation of comorbidities reduction. There was no monitoring of iron levels, evaluation of other micronutrients, and neither was there follow-up after 12 months once the RUSF was withdrawn until the time of this report.

\section{Authors' contribution}

All authors collaborated in the conception and intellectual interpretation of the research. Juan O. Talavera carried out the final analyses; all authors approved the final version of the manuscript.

\section{Funding}

This research was funded and supported by PepsiCo Inc.

\section{Conflict of interests}

Mónica J. García-Vilchis, Ma. Fernanda Martínez-Jaureguiberry and Brenda Salgado-Enríquez are employees of PepsiCo Inc. The opinions expressed in this article are those of the authors and do not necessarily reflect the opinion or policies of that company.

\section{Ethical disclosures}

Protection of human and animal subjects. The authors declare that the procedures that were followed adhered to the ethical standards of the responsible committee for experimentation on human beings and were in agreement with the World Medical Association and the Declaration of Helsinki.

Confidentiality of data. The authors declare that they followed the protocols of their work center on the publication of patient data.

Right to privacy and consent. The authors obtained informed consent from the patients or subjects referred to in the article. This document is in the possession of the corresponding author.

\section{References}

1. United Nations SCN. $6^{\text {th }}$ Report on the World Nutrition Situation. Progress in Nutrition. Switzerland: United Nations; 2010.

2. Müller O, Krawinkel M. Malnutrition and health in developing countries. CMAJ. 2005;173:279-86

3. Food and Agriculture Organization. The State of Food Security and Nutrition in the World 2018: building Climate Resilience for Food Security and Nutrition. Italy: Food and Agriculture Organization of the United Nations/International Fund for Agricultural Development/United Nations Children's Fund/World Food Programme; 2018.

4. Horton S, Alderman H, Rivera JA. Copenhagen Consensus 2008 Challenge Paper: hunger and Malnutrition. Denmark: Copenhagen Consensus Center; 2008.

5. Black RE, Allen LH, Bhutta ZA, Caulfield LE, de Onis M, Ezzati M, et al. Maternal and child undernutrition: global and regional exposures and health consequences. Lancet. 2008:371:243-60.

6. Gutiérrez JP, Rivera-Dommarco J, Shamah-Levy T, Villalpando-Hernández S, Franco A, Cuevas-Nasu L, et al. Encuesta Nacional de Salud y Nutrición 2012. Resultados Nacionales. Mexico: Instituto Nacional de Salud Pública; 2012

7. Rivera JA, Irizarry L, González-de Cossío. Overview of the nutritional status of the Mexican population in the last two decades. Salud Pública Mex. 2009:51:S645-56.

8. Juárez B, González C. Food Security and Nutrition in Mexico. Mexico: Global Agricultural Information Network; 2010.

9. World Health Organization. Technical Note: supplementary Foods for the Management of Moderate Acute Malnutrition in Infants and Children 6-59 Months of Age. Switzerland: World Health Organization; 2012.

10. Trehan I, Banerjee S, Murray E, Ryan KN, Thakwalakwa C, Maleta KM, et al. Extending supplementary feeding for children younger than 5 years with moderate acute malnutrition leads to lower relapse rates. J Pediatr Gastroenterol Nutr. 2015;60:544-9.

11. Chang CY, Trehan I, Wang RJ, Thakwalakwa C, Maleta K, Deitchler M, et al. Children successfully treated for moderate acute malnutrition remain at risk for malnutrition and death in the subsequent year after recovery. J Nutr. 2013;143:215-20.

12. Stobaugh HC, Bollinger LB, Adams SE, Crocker AH, Grise JB, Kennedy JA, et al. Effect of a package of health and nutrition services on sustained recovery in children after moderate acute malnutrition and factors related to sustaining recovery: a cluster-randomized trial. Am J Clin Nutr. 2017;106:657-66.

13. De Caballero E, Sinisterra O, Lagrutta F, Atalah E. Evaluación del impacto nutricional del programa de alimentación complementaria de $\mathrm{Pa}$ namá en niños menores de 5 años. ALAN. 2004;54:66-71.

14. Naranjo CA, Busto U, Sellers EM, Sandor P, Ruiz I, Roberts EA, et al. A method for estimating the probability of adverse drug reactions. Clin Pharmacol Ther. 1981;30:239-45

15. World Health Organization. WHO Child Growth Standards and the Identification of Severe Acute Malnutrition in Infants and Children. Switzerland: World Health Organization/United Nations Children's Fund; 2009.

16. World Food Programme. A Manual: measuring and Interpreting Malnutrition and Mortality. Italy: Centers for Disease Control and Prevention/ World Food Programme; 2005

17. World Health Organization. WHO Child Growth Standards: methods and Development. Switzerland: World Health Organization; 2006.

18. Karakochuk C, van den Briel T, Stephens D, Zlotkin S. Treatment of moderate acute malnutrition with ready-to-use supplementary food results in higher overall recovery rates compared with a corn-soya blend in children in southern Ethiopia: an operations research trial. Am J Clin Nutr. 2012;96:911-6.

19. Ochoa-Tapia E, Ávila-Sánchez A, Montero-Farrera J, Pulido-Villarreal M, López-López D, Trujillo-Vizuet MG, et al. Evaluación de la recuperación nutricional en niños menores de cinco años con un suplemento alimenticio a base de soya, ajonjolí, amaranto y avena, en zonas rurales de Chiapas. Rev Endocrinol Nutr. 2013;21:107-13.

20. Stobaugh HC, Ryan KN, Kennedy JA, Grise JB, Crocker $\mathrm{AH}$, Thakwalakwa $C$, et al. Including whey protein and whey permeate in ready-to-use supplementary food improves recovery rates in children with moderate acute malnutrition: a randomized, double-blind clinical trial. Am J Clin Nutr. 2016;103:926-33.

21. Nikièma L, Huybregts L, Kolsteren $P$, Lanou $H$, Tiendrebeogo S, Bouckaert $\mathrm{K}$, et al. Treating moderate acute malnutrition in first-line health services: an effectiveness cluster-randomized trial in Burkina Faso. Am J Clin Nutr. 2014;100:241-9.

22. Rivera JA, Sotres-Álvarez D, Habicht JP, Shamah T, Villalpando S. Impact of the Mexican program for education, health, and nutrition (Progresa) on rates of growth and anemia in infants and young children: a randomized effectiveness study. JAMA. 2004;291:2563-70. 
23. Neufeld ML, Rivera-Dommarco J, Villalpando-Hernández S, Shamah-Levy T. Eficacia de los Suplementos Alimenticios del Programa Oportunidades en el Estado de Nutrición de Niños y Mujeres Mexicanos. México: Instituto Nacional de Salud Pública; 2003.

24. Bahwere P, Balaluka B, Wells JC, Mbiribindi CN, Sadler K, Akomo P et al. Cereals and pulse-based ready-to-use therapeutic food as an alternative to the standard milk- and peanut paste-based formulation for treating severe acute malnutrition: a noninferiority, individually randomized controlled efficacy clinical trial. Am J Clin Nutr. 2016:103:1145-61.

25. Nackers F, Broillet F, Oumarou D, Djibo A, Gaboulaud V, Guerin PJ et al. Effectiveness of ready-to-use therapeutic food compared to a corn/ soy-blend-based pre-mix for the treatment of childhood moderate in $\mathrm{Ni}$ ger. J Trop Pediatr. 2010;56:407-13.
26. López-de Romaña G. Experience with complementary feeding in the FONCODES project. Food Nutr Bull. 2000;21:43-8.

27. Penny ME, Creed-Kanashiro HM, Robert RC, Rocio-Narro M, Caulfield LE, Black RE. Effectiveness of an educational intervention delivered through the health services to improve nutrition in young children: a cluster-randomised controlled trial. Lancet. 2005;365:1863-72.

28. Dewey KG, AduIAfarwuah S. Systematic review of the efficacy and effectiveness of complementary feeding interventions in developing countries. Matern Child Nutr. 2008:4:24-85.

29. Talavera JO, García-Vilchis MJ, Labrada-Alba TS, Olvera-Flores F, Martínez-Jaureguiberry MF, Salgado-Enríquez B. Prevención de desnutrición aguda moderada con un suplemento alimenticio listo para consumir en niños preescolares de comunidades rurales. Gac Med Mex. 2020;156:499-508.

\section{Supplementry Tables}

Supplementary Table 1. Nutrimental composition of the ready-to-use supplementary food (RUSF)

\begin{tabular}{|c|c|c|}
\hline Nutriments & Nutriment source & Amount/serving* (50 g, 4 biscuits) \\
\hline Energy (kcal) & Oats, peanuts, starch, oil & 250 \\
\hline Protein $(g)^{\star \star}$ & Oats, peanuts, milk, eggs & 6 \\
\hline Lipids (g) & Oats, peanuts, oil & $12(43 \mathrm{TE})^{\star \star \star}$ \\
\hline Carbohydrates (g) & Oats, peanuts, starch & 29.5 \\
\hline Sodium (mg) & Oats, peanuts, milk, eggs & $<300$ \\
\hline Potassium (mg) & Potassium phosphate and potassium chloride & 300 \\
\hline Calcium (mg) & Tricalcium phosphate & $200(22.2 \%)$ \\
\hline Phosphorus (mg) & Potassium phosphate & $150(22.6 \%)$ \\
\hline Magnesium (mg) & Magnesium carbonate & $50(20.2 \%)$ \\
\hline Iron (mg) & Ferrous fumarate & $8(47.1 \%)$ \\
\hline Zinc (mg) & Zinc oxide & $7(70 \%)$ \\
\hline Copper $(\mu \mathrm{g})$ & Oats, peanuts, milk, eggs & $100(15 \%)$ \\
\hline lodine $(\mu \mathrm{g})$ & Potassium iodide & $90(90.9 \%)$ \\
\hline Vitamin A $(\mu \mathrm{g})$ & Retinyl palmitate & $300(52.8 \%)$ \\
\hline Vitamin $D_{3}(\mu \mathrm{g})$ & Cholecalciferol & $2(35.7 \%)$ \\
\hline Vitamin E (mg) & $\alpha$-tocopherol acetate & $5(45.5 \%)$ \\
\hline Vitamin $B_{1}(m g)$ & Thiamine mononitrate & $0.5(62.5 \%)$ \\
\hline Vitamin $B_{2}(m g)$ & Riboflavin & $0.5(59.5 \%)$ \\
\hline Vitamin C (mg) & Sodium ascorbate & $40(61.7 \%)$ \\
\hline Vitamin $B_{6}(\mathrm{mg})$ & Pyridoxine $\mathrm{HCl}$ & $0.5(53.8 \%)$ \\
\hline Vitamin $B_{12}(\mu \mathrm{g})$ & Cyanocobalamin & $1.2(57.1 \%)$ \\
\hline Folic acid $(\mu \mathrm{g})$ & Folic acid & $160(42.1 \%)$ \\
\hline Niacin (mg) & Niacin & $6(54.5 \%)$ \\
\hline
\end{tabular}

${ }^{*}$ Nutriments per RUSF serving. ${ }^{* *} 10 \%$ of total protein content from animal sources. TE: total energy. 
Supplementary Table 2. Nutrition, health and hygiene education program

No. Topic

1. Training

2. National health weeks importance

3. Anemia

4. Consequences of undernutrition

5. Recommended diet for preschool children

6. Healthy pregnancy

7. Breastfeeding

8. Early childhood stimulation

9. El Plato del Bien Comer, Mexican Food Guidelines

10. Parasitosis

12. Importance and consumption of inorganic nutrients

13. Vitamin A y and its benefits for health
11. Hygiene

\section{Objective}

Explain the purpose of the study, compliance, test products shared use prevention, test products proper storage and use

Encourage the community to participate in national health weeks by providing detailed information on when, where and what benefits will they receive

Explain the causes and consequences of anemia due to iron deficiency and how to treat and prevent anemia in small children

Explain the causes and consequences of undernutrition, offering comprehensive guidance on how to prevent it

Explain the characteristics and provide detailed recommendations on the selection and quantity of dietary guidance for children younger than 5 years

Promote awareness on the importance of receiving medical care and provide recommendations on food selection during this period

Raising awareness on the importance and health benefits of breastfeeding during the first 6 months of life

Explain the relevance of early stimulation for children younger than five years, as well as inclusion of its positive impact on neural development

Explain the Mexican Food Guidelines and identify the three main food groups in order to promote healthy eating

To describe the causes and consequences of intestinal diseases and provide guidance on how and when children should be given anti-parasitic treatment

To provide information on the importance of having good hygiene practices everywhere in order to avoid and prevent diseases

Explain the importance of consuming inorganic nutrients through a proper diet and their dietary sources

Explain the importance of vitamin A consumption through a proper diet and its dietary sources

The program included 24 face-to-face practical sessions in which a well-trained facilitator using printed/graphic materials, discussed each topic with the participants. Each topic was developed and presented in two 20-minute sessions every 14 days. 